\title{
Environmental Import Substitution in the System of Sustainable Development of the "Green" Economy
}

\author{
Anna Balabanova ${ }^{1}$, Alexey Kuznetsov ${ }^{2}$, and Nina Gostieva ${ }^{2, *}$ \\ ${ }^{1}$ Russian Academy of Entrepreneurship, Rector, 109544, Moscow, 15, Malaya Andronievskaya st., \\ Russia \\ ${ }^{2}$ Plekhanov Russian University of Economics, 117997, Moscow, 36 Stremyanny lane, Russia
}

\begin{abstract}
Currently, the economic systems of developed countries are undergoing structural transformations associated with the deployment of a new environmentally oriented industrial sector on a new technological environmentally friendly basis. For technologically catching-up countries, including those focused on the extraction of natural resources, the task is to critically understand the modification of this trend, since the deindustrialization processes led to the loss of many modern manufacturing industries, which resulted in a deep import dependence on resource-saving technologies and equipment. This results in the wasteful use of the resource base of the economy and the lack of recycling, in increasing pollution and lagging behind in terms of environmental industrial technologies. Ineffective institutions and international financial and technological restrictions reduce the effect of stimulating environmental import substitution by the state, hinder the development of its reproductive mechanisms that can provide a positive trend in economic dynamics. Therefore, the development of environmental import substitution, integrating the resource availability of the economy and environmental imperatives, technologies for the careful use of resources and their recycling, determines the prospects for sustainable development of the economy as a whole.
\end{abstract}

\section{Introduction}

Scientific discussions about the "green" development of the economy of technologically catching up and resource-producing countries have been going on for a long time [1-3]. One of the key areas is the impact of Industry 4.0 on the transition to a green economy [4]. Most of the economies of resource-producing countries are still "brown"; based on burning fossil fuels or receiving the main income from the export of oil and gas [5]. In view of such a significant dependence on fossil fuels, the transition to a "green" economy is not an easy task, for the solution of which it is necessary to create new environmental technologies and domestic production of resource-saving equipment [6]. In fact, this means the formation of a new type of import substitution - environmental one [7].

\footnotetext{
* Corresponding author: Gostieva.NK@,rea.ru
} 
At the global level of industrial development, the United Nations Conference on Trade and Development (UNCTAD) in 2016 noted a global demand for the development of its own industries for the domestic market from the emerging markets of Europe, Southeast Asia, Latin America and Africa. It is dictated by the growth of the debt of their non-financial corporations from 9 to 25 trillion dollars for $2008-2015$ (from $57 \%$ to $104 \%$ of their total GDP) as a consequence of the deficit of their trade balances [8].

Reconstruction of the manufacturing industry in order to saturate the domestic market with environmental technologies and resource-saving equipment is relevant both for catching-up and technologically advanced countries. For transitive economies, import substitution requires an accelerated innovative development of industry, and in a number of branches - the reconstruction of manufacturing industries lost during the market reforms and overcoming their technological degradation [9]. For technologically advanced countries, this means reshoring industrial structures on the country territory after several decades of transferring material production abroad. At the same time, in the Russian economy, the capacious domestic market of means of production and modern technologies is largely saturated with imports, which have taken key positions both in the preferences of consumers and in technological chains [10]. Therefore, when purchasing new equipment, industrial companies are guided primarily by productivity and costs, rarely taking into account the environmental consequences of production modernization [11]. On the contrary, environmental import substitution, being part of a long-term strategy of sustainable development, should be aimed at the development of competitive industries focused on modern environmental standards and norms of resource consumption, and not at crowding out imported means of production [12].

\section{Materials and Methods}

Initially, the phenomenon of import substitution is considered in the context of increasing the market advantages of the national economy in the world trade system. Raul Prebisch's views [13] on the ratio of exports and imports formed the basis of the theory of "peripheral capitalism", according to which in countries that mainly import finished goods and export raw materials, there is a "reproduction of deprivation", which affects not only the structure of the economy, but also demographic processes, ecological situation, political system.

The English economist Hans Singer arguably proved that the balance of prices for enduse products and raw materials prices in the future 10-15 years is not in favor of countries whose economies are specialized in the extraction, primary processing and export of natural resources [14]. The economic system of these countries is characterized by H. Singer as "peripheral capitalism", which over time lags behind technologically advanced economies.

Later P.B. Clark, D.E. Logue, R.J. Sweeney proposed a "model of perfect substitutes" [15]. R.R. Rhomberg [16], M. Goldstein, M.S. Khan, and L.H. Officer [17] offered a "model of imperfect substitutes" that describe the possibilities of import substitution in competitive markets. The "model of perfect substitutes" means "switching" by consumers from imported goods to domestic ones without significant costs for them, since the competitiveness of domestic producers often turns out to be higher than expected in practice. The model of imperfect substitutes implies limiting price competition between imported and domestic goods, which explains the fact that even at lower prices, foreign products are not able to replace the results of the production of goods within the country.

It should be noted the importance of studying the problems of the impact of import dependence on the country's environmental safety [18]. Reducing dependence on imports of modern resource-saving equipment and "green" technologies in a lagging economy is possible only within the framework of such import substitution, which is associated with the 
transfer of most of the elements of global production chains to the country, and the restoration of the technological identity of the manufacturing industry [19].

Thus, in relation to the need for the greening of industrial production in catching-up countries, we give a more precise definition of import substitution - as a restoring the production of goods in the economy with an international level of environmental protection for domestic market within targeted structural change of economy, relying on combination of domestic demand potential and stimulating innovative development of industry.

The inalienability of such environmental import substitution from the process of structural transformation of the economy means the implementation of its following functions:

- economic - the revival of business activity, the creation of jobs in manufacturing and hightech industries, in which low competitiveness has led to the replacement of their products by imports;

- environmental - using the potential of the internal market to improve the environmental level of the industry, increase the competitiveness of its "green" segment;

- anti-recessive - protection of the economy from external shocks associated with fluctuations in prices for mineral raw materials, in the context of radical macroeconomic imbalances.

\section{Results and Discussion}

Environmental import substitution is a set of mechanisms for regulating the genesis of the "green" economy - both macroeconomic and sectoral, pursuing short-term and long-term goals. These mechanisms include the following: [20-22]

- protectionism is an exogenous factor in achieving environmental safety by restricting imports of food and consumer goods, the production and consumption of which increases the pressure on the environment. This implies the adoption of measures that restrict imports and expand consumer demand for the output of domestic companies (customs duties, embargoes, subsidies, soft loans, technical barriers, etc.). However, protectionism, pursuing short-term goals of protecting the national natural system and the market of "green" goods, contradicts the idea of import substitution as a driver of technological modernization of industry towards a "green" economy, relying on the economic potential of the domestic market, and does not create conditions for the growth of competitiveness of resource-saving technologies and recycling in the domestic market;

- the implementation of endogenous factors in the development of the national reproductive system (investment, innovation, employment, consumer spending) aimed at long-term changes in resource consumption. Environmental import substitution is a system in which inter-sectoral and inter-branch redistribution of investments, labor force, incomes is implemented, and the reproduction of human capital is accelerated.

- the greening of market transformations of the economy in the process of stimulating employment in the manufacturing and high-tech sectors of the "green economy", income growth and the activation of social lifts associated with environmental protection and environmental entrepreneurship.

The principles of environmental import substitution are the following:

1. Conditionality by structural transformations and the development of economic relations in the environmental sphere. The connection between import substitution and the complex of processes accompanying the formation of a "green" economy consists in the modification of economic relations in the reproduction system, in the formation of their new subjects and new ties between the state and market actors. The development of economic relations in the reproduction system is associated with the accumulation of investment resources and innovative activities financing, with the distribution of investment income, with the 
formation of an institutional framework for import-substituting investments (correction of laws, arranging of long-term investment contracts, changes in ethical standards of investment) [23]. All this forms the initial basis of environmental import substitution as a mean of establishing a "green" economy, in the process of creating from scratch environmentally friendly production of "green" goods, assessed by domestic consumers as competitive with respect to imports.

The state policy of environmental import substitution means the use of economic regulation tools used to change the proportions between the irretrievable use of resources and their recycling, accelerate the introduction of environmental achievements of scientific and technological progress in production, greening consumption - that is, structural policy [24].2. 2. The specificity of the environmental import substitution as a component of sustainable development of the "green" economy is, firstly, the maximum consideration of the requirements of domestic consumers (both means of production and resources, as well as the benefits of final demand) for an increase in the environmental component of the quality of life. Second, the success of environmental import substitution is determined by a decrease in unit costs to win over imports in price competition. And this, in turn, is possible only with a significant reduction in the cost of investment resources and ensuring a massive inflow of investments in environmental modernization and innovative development of industry as part of the formation of a "green" economy.

Strategic programming combining short-term protectionism and stimulating the development of industrial segments represented by resource-saving technologies and recycling is very important. Since environmental import substitution implies the implementation of the state's economic policy aimed at overcoming the environmental consequences of the growth in the extraction of natural resources and their consumption, it should rely, on the one hand, on the strategy of protecting domestic markets from foreign products that do not meet modern environmental standards (prohibitive custom duties, import quotas etc.) [25]. On the other hand, the government's turning to the domestic market as a source of effective demand for "green" domestic products means the development and fulfilling of a strategy to support the demand for technologies, equipment and goods dominating in imports with a high level of environmental safety. It can be achieved by subsidizing and crediting their production and purchasing, funding the enterprises, joint financing of $R \& D$ in this area with the business.

These strategies - protectionism and investment in environmental import substitution should be coordinated parts of the state's environmental policy in industry, which ultimately determine the structure of national reproduction in the long term. Since they should be aimed at encouraging domestic business to long-term investment in resource-saving production and the development of recycling, in order to obtain the desired result, they should not be replaced solely by protectionism. Consequently, in the system of environmental import substitution, protectionist measures should be short-term, supporting structural policy measures at the first stage, initiating a reorientation of demand for domestic production of the "green" economy. 3. Priority substitution of imports of means of production within the framework of publicand-private partnerships, carried out in parallel with the advanced import of recycling technologies. Environmentally oriented industrial growth, which requires accelerated innovative development of manufacturing industries and the use of their products for the development of resource-saving industries, is impossible without the development of technologies to improve labor safety, especially in the extractive industries [26]. Domestic machinery and the production of modern materials for industrial consumers is also must accompany environmental import substitution [27]. However, in these sectors of the Russian economy imports exceed domestic production by 3-4 times, due to non-innovative products and high operative costs [28]. 
It should be noted that the process of environmental import substitution is associated with certain risks that can manifest both at the macroeconomic and meso-economic (sectoral) levels [29-30]. These risks include:

- maintaining the low competitiveness of domestic producers of means of production and end-use goods of the "green" economy due to long-term state protectionism and stagnation of effective demand;

- continuation of technological degradation and an increase in the lag of manufacturing industries from international requirements for competitiveness as a result of the development of environmental import substitution along the "catch-up" path, without comprehensive stimulation of the substitution of imports of environmentally friendly technologies and means of production;

- an increase in budget spending and corruption as a result of the expansion of public purchase and industrial subsidies;

- consolidation of the recessive trend in case of prolonged protectionism of the domestic industry, delaying the transition to a "green" economy.

\section{Conclusion}

The proposed concept of environmental import substitution in the Russian economy of a technologically catching-up type is based on the systematic formation of favorable conditions for the reproduction of industrial, intellectual and social capital corresponding to modern technological structures, the launch of cluster mechanisms for the accelerated innovative development of the manufacturing sector, and stimulation of domestic demand for its products. A special place in the proposed concept of environmental import substitution is occupied by the priority of stimulating the recreation of the output of resource-saving means of production for the needs of the domestic industry. Initiation of environmental import substitution in the Russian economy requires the development of the institution of publicand-private partnership in order to effectively use state-owned factories and intellectual property. The development of such a partnership means the formation of a neo-industrial alliance of the state and business in the form of long-term contracts of the life cycle of innovations, design, modernization and implementation partnerships, a pool of buyers of domestic equipment, a guarantee fund of for investments and long-term loans to importsubstituting enterprises.

\section{References}

1. S. Khouri, H. Pavolová, M. Cehlár, T. Bakalár, Metalurgija 55(3), 500-502 (2016)

2. S.A. Zhironkin, Ugol' 6, 62-63 (2001)

3. V. Trifonov, O. Loyko, D. Nesteruk, S. Zhironkin, E. Strekovtsova, AIP Conference Proceedings 1800, 050009 (2017)

4. D. Szurgacz, J. Brodny, International Multidisciplinary Scientific GeoConference Surveying Geology and Mining Ecology Management, SGEM 17(13), 47-54 (2017)

5. S. Zhironkin, A. Selyukov, M. Gasanov, Energies 13(13), 3305 (2020)

6. S. Zhironkin, M. Gasanov, G. Barysheva, E. Gasanov, O. Zhironkina, G. Kayachev, E3S Web of Conferences 21, 04002 (2017)

7. S.A. Zhironkin, K.A. Kolotov, O.V. Zhironkina 1, 4-16 (2017) DOI: 10.26730/25875574-2017-1-4-16

8. United Nations Conference on Trade and Development. Trade and Development Report, 2016 (UNCTAD, Geneva, 2016) 
9. M.A. Klimovich, M.A. Gasanov, Economics and Innovation Management 2, 8-17 (2019) DOI: $10.26730 / 2587-5574-2019-2-8-17$

10. K.B. Kvitko, Economics and Innovation Management 1, 26-35 (2019) DOI: 10.26730/2587-5574-2019-1-26-35

11. M. Tyulenev, S. Markov, M. Cehlar, S. Zhironkin, M. Gasanov, Acta Montanistica Slovaca 23(4), 368-377 (2018)

12. B. Gerike, Yu. Drozdenko, D. Kopytin, Journal of Mining and Geotechnical Engineering 3, 58-78 (2020) doi: 10.26730/2618-7434-2020-3-58-78

13. R. Prebisch, The Economic Development of Latin America and Its Principal Problems (New York: United Nations, 1950)

14. J. Toye, Cambridge Journal of Economics 30, 819-833 (2006)

15. P.B. Clark, D.E. Logue, R.J. Sweeney, The Effects of Exchange Rate Adjustments (U.S. Government Printing Office, Washington, D.C, 1977)

16. R.R. Rhomberg, Toward a General Trade Models. The International Linkage of National Economic Models (North-Holland, Amsterdam, 1990)

17. M. Goldstein, M.S. Khan, L.H. Officer, The Review of Economics and Statistics 62(2), 190-199 (1980)

18. D.A. Shchedrova, V.T. Borisovich, Y.A. Leonidova, Economics and Innovation Management 2, 37-43 (2018) DOI: 10.26730/2587-5574-2018-2-70-76

19. E.V. Shavina, Economics and Innovation Management 3, 4-13 (2019) DOI: 10.26730/2587-5574-2019-3-4-13

20. A.V. Myaskov, S.M. Popov, Economics and Innovation Management 1, 16-24 (2018) DOI: $10.26730 / 2587-5574-2018-1-16-24$

21. A.N. Tokarev, Economics and Innovation Management 1, 25-35 (2018) DOI: 10.26730/2587-5574-2018-1-25-35

O.E. Kalenov, S.N. Kukushkin, Economics and Innovation Management 3, 88-96 (2020) DOI: 10.26730/2587-5574-2020-3-88-96

22. S.A. Zhironkin, Ugol' 4, 47-49 (2002)

23. A.G. Koryakov, M.V. Kulikov, Economics and Innovation Management 4, 16-26 (2018) DOI: $10.26730 / 2587-5574-2018-4-16-26$

24. S.A. Zhironkin, K.A. Kolotov, A.E. Genin, F.V. Agafonov, S.A. Kovalevsky, IOP Conference Series: Earth and Environmental Science 50(1), 012011 (2017)

25. 26. D. Szurgacz, M. Tutak, J. Brodny, L. Sobik, O. Zhironkina, Energies 13(17), 4538 (2020) DOI: 10.3390/en13174538

26. S. Zhironkin, S. Demchenko, G. Kayachev, M. Ryzhkova, O. Zhironkina, E3S Web of Conferences 41, 04011 (2018)

27. M. Tyulenev, E. Garina, A. Khoreshok, O. Litvin, Y. Litvin, E. Maliukhina, IOP Conference Series: Earth and Environmental Science 50(1), 012035 (2017)

28. E.Y. Dotsenko, N.P. Ezdina, A.S. Khasanova, M.I. Khasanov, E3S Web of Conferences 247, 01068 (2021)

29. Amirova N., Sargina L., Khasanova A., E3S Web of Conferences 174, 02011 (2020)

30. Gostieva, N., Kazarinova, E., Samarina, E., Balabanova, A., E3S Web of Conferences 174, 04037 (2020) 